\title{
Characteristics of Logistics Outsourcing in Bulgaria: The Perspectives of the Logistics Service Providers and their Customers
}

\author{
Miroslava RAKOVSKA ${ }^{1}$ \\ 1 University of National and World Economy/Logistics Department, Sofia, Bulgaria
}

\begin{abstract}
The increased demand and supply of logistics services bring together the logistics service providers (LSPs) and the companies that outsource logistics activities. LSPs stand in between those companies and their customers, thus playing an essential role for supply chain integration. If the two parties have different viewpoints of the processes in the supply chain, the fulfillment of the goal to satisfy the end customers may be hindered. The purpose of this article is two-fold: First, to investigate the characteristics of logistics outsourcing in Bulgaria from the perspectives of the logistics service providers and their customers, and more specifically, to compare their viewpoints concerning the motives for outsourcing, the methods and contents of communication and some relationship management aspects; Second, to assess the relations of the communication and relationship management aspects to customer satisfaction. This article is based on empirical data provided by 138 manufacturing and trading companies and 136 LSPs and collected through two structured questionnaires designed to address the researched issues. The data were analyzed using descriptive statistics and the independent samples t-test. The research found that the service related reasons for logistics outsourcing are prevailing and that LSPs overestimate, compared to manufacturing and trading companies, motives related to service, organizational capabilities and relationships, while more manufacturing and trading companies concern as important the availability of logistics assets and the provision of value-added services. The research also found that both the LSPs and their customers consider that the extent of sharing of knowledge and information essential for material flow integration is very low and that the usage of team meetings and joint teams is quite rare. Also, customers do not view their relationships with the LSPs as so collaborative as viewed by the LSPs. Furthermore, the research proved the existence of positive relationships between customer satisfaction and communication through team meetings and joint teams, knowledge sharing concerning material flow management and relationship management issues such as trust, mutual problem solving, understanding the logistics strategy of the other party and respecting its financial interests. The research findings may help fill in some of the gaps between LSPs and their customers. They point the need for LSPs to include in their service offerings more value-added services and to invest in assets that provide reliable and flexible services for their customers. The research also highlights the importance of knowledge sharing and trust building and reveals great potential for effective trust-based alliances between LSPs and their customers that could help them extract more competitive benefits from their relationships.
\end{abstract}

Key words-Logistics outsourcing, logistics service providers, outsourcing motives, communication, relationship management.

\section{INTRODUCTION}

Logistics outsourcing has grown significantly throughout the world. The application of logistics in manufacturing and trading companies increased the demand for logistics services which led to the rapid development of the logistics sector. The reasons for outsourcing can be rooted either in cost reduction or in customer service improvement as well. On the other hand, the complexity and globalization of the logistics activities and the need for their integration stimulate the supply of a variety of logistics services. As a result, logistics service providers (LSPS) and their customers are working together for the provision of high service levels for the end customers. The position of the LSP between a company and its customers forms a logistics triad with a key role in handling endcustomer information and feedback [1]. Therefore, the collaboration between companies in this triad is essential for supply chain integration. Collaborative relationships offer potential valuable benefits such as improving cooperation, information sharing, overall performance, and creating innovative business approaches and solutions [2].

A significant body of research has investigated different aspects of logistics outsourcing: types of outsourced activities, motives for outsourcing, criteria for selecting LSPs, benefits and risks of 
outsourcing, logistics services quality, performance, etc. What is more, these studies have been conducted in a number of countries and regions from different continents. Diverse methodologies have been used to reflect different viewpoints: the one of the LSPs, that of their customers, and those of both parties as well. A minority of research reveals the viewpoints of LSPs and their customers together. It concerns basically services offered and those required [3], quality management and performance issues [1], benefits of outsourcing [4], the development of strategic alliances [5], performance benefits resulting from the on-site location of employees [2]. These works have contributed to an understanding of what services are purchased and what is the effect of this decision. Little attention has been given in literature to the understanding of the viewpoints of both the LSPs and their customers concerning the motives for outsourcing, different facets of communication and the relationships between the parties, and the effects these facets have on customer satisfaction.

The purpose of this article is two-fold: First, to investigate the characteristics of logistics outsourcing in Bulgaria from the perspectives of the logistics service providers and their customers, and more specifically, to compare their viewpoints concerning the motives for outsourcing, the methods and contents of communication and some relationship management aspects; Second, to assess the relations of the communication and relationship management aspects to customer satisfaction.

The article addresses this purpose as follows: In the second section an overview of the relevant literature is presented revealing the addressed issues in the logistics outsourcing research. The third section presents the methodology used in this research. In the fourth one the characteristics of logistics outsourcing in Bulgaria are discussed, with emphasis on issues, which are viewed in different ways by customers and LSPs. The fifth section presents the results of the research concerning the relations of communication and relationship management aspects to customer satisfaction. Finally, conclusions are drawn and research implications and brought out.

\section{OVERVIEW OF LITERATURE}

Logistics outsourcing has become a major trend in contemporary businesses. Many researchers have examined it from different perspectives. Ref. [6] surveyed logistics outsourcing practices of firms in the UK from 1990 to 2003 examining the customers' perceptions of logistics services provided by LSPs and the relationships they have with them. The authors found a change in the customers' main reasons for outsourcing their logistics functions from service to cost-related factors. In fact, cost reduction and service improvement expectations are the most frequently appearing in literature reasons for outsourcing logistics activities $[7,8]$. In addition to cost and service, myriad other factors can be extracted from previous research. Ref. [5] also looked into the nature of the most relevant reasons for logistics outsourcing based on literature review. They state that a company may pursue it for one or more of the following reasons: lack of logistics expertise; the desire to focus on its core competency; the difficulty in maintaining communication and information technology that is up to date; the desire to improve system capabilities along the global supply chain; and the desire to build flexibility within available resources. Other factors to add to these ones are limited logistics resources, improvement of productivity, information technology capabilities of LSPs, a need to react to changes in the regulatory environment, globalization and complexity of business, a need for just-in-time deliveries. Recent research revealed a greater focus on service-related motives. Ref. [9] surveyed manufacturing and trading firms and discovered that cost savings together with flexibility and customer service were the major motives for outsourcing. Another study among manufacturing and 3PL companies also discussed the role of service quality as a driver to outsource logistics services and as a criterion to select a logistics provider [1]. It proves that LSPs are ahead of manufacturing companies in all quality related issues. The extensive variety of factors that influence the decision to outsource logistics activities indicates that firms consider LSPs to have many valuable capabilities that can help them deal with the business challenges.

A number of studies identified factors critical to the success of logistics outsourcing efforts. One of them included a focus on sharing of information, joint development of strategies, and synchronizing operations [10]. Another important work on collaboration relating to the exchange of information efforts is that of Ref. [2]. Their research used matched dyadic survey data to assess performance benefits resulting from the on-site location of employees. They also explored how this relationship has an effect on knowledge sharing and logistics innovation between the LSP and the host firm and the impact of logistics innovation on the performance of both the LSP firm and the customer. Having in mind that knowledge is the information organized in such a way as to provide value [11] and that the ability to exchange knowledge internally within the firm and externally between 
partners creates the opportunity to combine knowledge for value creation [12], it can be concluded that the type of communication between the parties can influence the benefits for them. This conclusion also finds support in a study which evidenced that information Integration, in addition to $3 \mathrm{PL}$ selection criteria, $3 \mathrm{PL}$ performance evaluation criteria and relationship building, is a strategic enabling factor positively related to firm performance outcomes [13].

The above discussion brings to the forefront the increasing role of LSPs in the value-added supply chain processes. For that reason it is of key importance for outsourcing companies to establish a strategic alliance with logistics providers. Nevertheless, it is a meticulous and tedious process to achieve the highly desirable fidelity in the resulting relationship [5]. Indeed, the study of Ref. [6] revealed a clear trend towards the development of longer term partnerships. Some benefits to developing relationships between supply chain members include reduced costs, process improvements, quality enhancements, and profit growth [14]. Ref. [15] argued that collaborative relationships increase the opportunities for companies to access to unique tools for creating value. Their positive effects on costs and performance come basically from complementing capabilities and better information sharing [16].

According to Ref. [6], customer satisfaction with the provided logistics services is one of the crucial areas in which the performance of the LSPs could be evaluated. The authors found a relatively little change in the customer satisfaction level for a period of eight years. Nevertheless, the academic research has generally concentrated on the effects of different logistics outsourcing practices on firm performance. For example, Ref. [1] investigated the relationship between quality management status and financial performance in the context of $3 \mathrm{PL}$ providers. In a study of different levels of outsourcing logistics activities Ref. [17] discovered that, when outsourcing distribution network management activities (the highest level), the logistics service performance (delivery reliability, flexibility and lead-time) increased with an increasing degree of demand complexity. In addition to comparing the attitudes of the 3PL providers and their customers on a range of dimension, Ref. [4] found that there is significant association between 3PLs' competitive priorities, 3PLS' service and 3PLs' use of technologies, on one side, and contribution of the 3PL to customer performance, on the other side. The crucial contribution of LSPs to their customers' performance brings to the forefront their strategic role for company success. In this line, Ref. [18] developed a data-driven descriptive model of logistics outsourcing strategy that explores the experiences of logistics professionals.

This literature review demonstrates that there are a few works that survey both LSPs and their customers and none of them tackled simultaneously issues such as motives for logistics outsourcing, methods and content of communication and aspects of outsourcing relationship. Also the majority of research works tested the existence of relationships between logistics outsourcing aspects and company performance. In the context of the increasing length of contracts, no investigation was found into how communication and relationship management issues influence customer satisfaction. These untapped research areas allow the raising of the following research questions:

1. Is there any difference between the assessments of LSPs and their customers of the motives for outsourcing, methods and contents of communication, and some aspects of relationship management?

2. What are the relations of the methods and contents of communication and the aspects of relationship management to customer satisfaction?

The answers to these questions could help managers decrease the differences in LSPs' and customers' perceptions of important issues through application of the practices that increase customer satisfaction.

\section{METHODOLOGY}

The data for this research were collected through two separate structured questionnaires designed to address the researched issues in LSPs and their customers - manufacturing and trading companies. Responses were measured via 5-point scales. To assess the motives for outsourcing, respondents in manufacturing and trading companies were asked to point out the extent to which the listed motives are important for them to use the services of the LSPs and respondents in LSPS were asked to point out the extent to which the listed items are motives for their customers to use their services (1-not important; 5-extremely important). A set of thirty five items were provided for this question to encompass most of the relevant motives extracted from literature. In the next two questions respondents were asked to evaluate the usage of four basic communication methods (1-not used; 5-extremely used) and the extent of occurrence of ten areas in the communication with the corresponding party (1-never; 5 -very often). Ten possible relationship characteristics were 
proposed to respondents in both groups in order to rate their relevance for the outsourcing relationships from 1 (not relevant) to 5 (extremely relevant). Lastly, the level of customer satisfaction was measured only in the group of the LSPs' customers on a 5-point scale with 1 meaning "not satisfied" and 5 meaning "extremely satisfied". Scales from research existing in literature were utilized and adapted. Preliminary drafts of the survey questionnaires were reviewed by five experts from LSPs, three from manufacturing companies and three from trading companies. After receiving their opinion revised survey instruments were created.

Data was collected from February 2015 to July 2015. Questionnaires were distributed via e-mail or filled in through personal interviews. All companies had been contacted by phone and informed about the purpose of the survey to receive their agreement to participate. The total number of received questionnaires is 274 , of which 138 are filled by manufacturing and trading companies and 136 - by LSPs, i.e. the size of the two samples are almost equal. Trading companies represent $35,5 \%$ of the customers, while the share of the manufacturing companies is nearly twice bigger than that $(64,5 \%)$. Concerning the number of employees, $63 \%$ of the LSPs are micro and small enterprises with a number of employees below 50, and nearly one fifth of them are large enterprises with more than 250 employees. The share of the micro and small enterprises in the customers' sample is smaller $-47 \%$, while the share of the large enterprises in this sample is almost the same as the one of the LSPs $-21,2 \%$.

The data were analyzed with SPSS version 17.0. Independent samples t-test analysis was employed to find whether the two groups have significantly different mean values of responses. In order to assess the relations of communication and relationship management issues to customer satisfaction, the parametric t-test was used again. All customers were classified into two groups depending on the mean of the customer satisfaction variable. Then the t-test is run to assess the differences between the highly satisfied group (with satisfaction scores higher than or equal to the sample's mean) and the group with a lower satisfaction level concerning the various aspects of communication and relationship management.

\section{Assessment of the Characteristics of Logistics Outsourcing}

\section{A. Motives}

Table 1 shows the results of the analysis of the outsourcing motives which are listed in a descending order according to the means of the total sample. Most of the motives receive values over 3 and this result signifies that the motives viewed as important by companies are very diverse. The top five motives are related to the quality and flexibility of services, and also to LSPs' organizational factors such as reputation and experience. Surprisingly, the low costs motive is ranked 27 th among the firms.

There are significant differences between the two groups of companies in half of the motives. In total, LSPs give higher emphasis on these motives compared to manufacturing and trading companies except for the availability of contemporary logistics assets and the provision of valueadded services, which are more valued by customers. The more often mentioned motives by LSPs include service related ones such as service quality, short and reliable delivery times (more than $90 \%$ of LSPs give high importance to these motives), high frequency of deliveries to a destination (80\%), and capability to handle special deliveries (82\%). They also rate higher the motives concerning their organization as a whole such as reputation (90\%), business experience including experience in customer's industry (85\% and $76 \%$ respectively), financial stability $(76 \%)$, human resources quality (77\%) and management capabilities (78\%). LSPs consider as more important relationship related areas as well such as potential for long-term relationship development (80\%), a will and skills for cooperation and coordination (63\%) and existence of personal relationships (56\%).

These results indicate that the more often cited motives by the LSPs are more diverse, including elements of service, organizational capabilities and relationships. On the other hand, more manufacturing and trading companies than LSPs view as important or extremely important the availability of logistics assets, in which they wouldn't invest, and the provision of value-added services. This, as well as the fact that service related issues are rated highest, point to the need for LSPs to include in their service offerings more value-added services and to invest in assets that provide reliable and flexible services for their customers.

Table 1. Motives for outsourcing logistics services

\begin{tabular}{|l|l|l|l|l|l|}
\hline Motives & Mean & Responses & Responses & Groups & Group's \\
\hline
\end{tabular}


Logistics \& Sustainable Transport

Vol. 7, No. 1, October 2016, 18-27 doi: 10.1515/jlst-2016-0002

\begin{tabular}{|c|c|c|c|c|c|}
\hline & & $\begin{array}{l}4-5(\%) \text { for } \\
\text { customers }\end{array}$ & $\begin{array}{l}\text { 4-5 (\%) for } \\
\text { LSPs }\end{array}$ & & mean \\
\hline \multirow{2}{*}{ High service quality*** } & \multirow{2}{*}{4,40} & \multirow{2}{*}{83,6} & \multirow{2}{*}{92,6} & Customers & 4,25 \\
\hline & & & & LSPS & 4,55 \\
\hline \multirow{2}{*}{ Short delivery time $* * *$} & \multirow{2}{*}{4,35} & \multirow{2}{*}{79,1} & \multirow{2}{*}{94} & Customers & 4,16 \\
\hline & & & & LSPS & 4,53 \\
\hline \multirow{2}{*}{ Reliability of delivery time** } & \multirow{2}{*}{4,32} & \multirow{2}{*}{77} & \multirow{2}{*}{93,3} & Customers & 4,18 \\
\hline & & & & LSPS & 4,46 \\
\hline $\begin{array}{l}\text { Capability to cope with urgent } \\
\text { deliveries }\end{array}$ & 4,13 & 79,1 & 78,9 & & \\
\hline \multirow{2}{*}{ Good reputation*** } & \multirow{2}{*}{4,12} & \multirow{2}{*}{66,4} & \multirow{2}{*}{89,6} & Customers & 3,84 \\
\hline & & & & LSPS & 4,40 \\
\hline \multirow{2}{*}{ Business experience $* * *$} & \multirow{2}{*}{3,99} & \multirow{2}{*}{64,2} & \multirow{2}{*}{85,2} & Customers & 3,69 \\
\hline & & & & LSPS & 4,30 \\
\hline \multirow{2}{*}{$\begin{array}{l}\text { Potential for long-term relationship } \\
\text { development** }\end{array}$} & \multirow{2}{*}{3,96} & \multirow{2}{*}{69,4} & \multirow{2}{*}{80} & Customers & 3,82 \\
\hline & & & & LSPS & 4,11 \\
\hline Low frequency of losses and damages & 3,95 & 73,9 & 74,4 & & \\
\hline Track and trace capability & 3,88 & 69,4 & 71,6 & & \\
\hline \multirow{2}{*}{$\begin{array}{l}\text { High frequency of deliveries to a } \\
\text { destination** }\end{array}$} & 388 & 612 & 799 & Customers & 3,71 \\
\hline & 0,00 & 01,2 & 19,9 & LSPS & 4,04 \\
\hline $\begin{array}{l}\text { Provision of detailed information } \\
\text { before, during and after the delivery }\end{array}$ & 3,86 & 71,6 & 68,2 & & \\
\hline Financial stability**** & 384 & 604 & 758 & Customers & 3,63 \\
\hline Fillanctal staiominy*** & 0,04 & 00,4 & 15,8 & LSPS & 4,04 \\
\hline Capacity availability & 3,83 & 69,9 & & & \\
\hline Capability to handle special & 376 & & & Customers & 3,38 \\
\hline deliveries*** & 3,10 & 34,1 & 82 & LSPS & 4,14 \\
\hline Human resources quality**** & 372 & 582 & 769 & Customers & 3,46 \\
\hline HU⿴囗十⺝ & $0,1 / 2$ & 30,2 & 10,7 & LSPS & 3,99 \\
\hline Mangaement canghilities*** & 365 & 455 & 778 & Customers & 3,24 \\
\hline 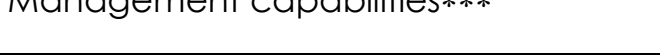 & 0,00 & 43,0 & 11,8 & LSPS & 4,05 \\
\hline Experience in the customer's & 362 & 515 & 722 & Customers & 3,40 \\
\hline industry*** & & & & LSPS & 3,83 \\
\hline $\begin{array}{l}\text { Usage of contemporary information } \\
\text { and communication technologies }\end{array}$ & 3,61 & 56,4 & 59,4 & & \\
\hline Broad geographical coverage & 3,52 & 56,7 & 56,8 & & \\
\hline Special offers (discounts) & 3,45 & 58,5 & 50,4 & & \\
\hline Simnlified invoicing**** & 3.43 & 485 & 63.1 & Customers & 3,17 \\
\hline simpilled IIVOCICIIg*** & 0,40 & 40,3 & 03,1 & LSPS & 3,70 \\
\hline A will and skills for cooperation and & & & & Customers & 3,05 \\
\hline coordination $* * *$ & $3,3 /$ & 34,8 & 63,3 & LSPS & 3,70 \\
\hline Availability of contemporary logistics & 3,34 & 556 & 412 & Customers & 3,50 \\
\hline assets** & & & & LSPS & 3,18 \\
\hline $\begin{array}{l}\text { Location (closeness to plant or } \\
\text { warehouse) }\end{array}$ & 3,17 & 38,5 & 48,1 & & \\
\hline IT compatibility & 3,16 & 45,9 & 45,9 & & \\
\hline Low costs & 3,15 & 60 & 47,7 & & \\
\hline Provision of variety of services & 3,15 & 47,4 & 50,4 & & \\
\hline
\end{tabular}


Logistics \& Sustainable Transport

Vol. 7, No. 1, October 2016, 18-27 doi: 10.1515/jlst-2016-0002

\begin{tabular}{|c|c|c|c|c|c|}
\hline Compatibility of logistics technologies & 3,12 & 39,8 & 43,2 & & \\
\hline \multirow{2}{*}{ Existence of personal relationships*** } & \multirow{2}{*}{3,10} & \multirow{2}{*}{33,8} & \multirow{2}{*}{55,8} & Customers & 2,73 \\
\hline & & & & LSPS & 3,47 \\
\hline $\begin{array}{l}\text { Knowledge and recommendations for } \\
\text { innovations and improvements in } \\
\text { logistics }\end{array}$ & 3,06 & 42,1 & 43,5 & & \\
\hline Opportunities for e-business & 2,96 & 42,1 & 40,2 & & \\
\hline $\begin{array}{l}\text { Certifications (quality, HACCP, and } \\
\text { others) }\end{array}$ & 2,92 & 42,1 & 40,6 & & \\
\hline $\begin{array}{l}\text { Integrated operations and } \\
\text { technologies between regions, } \\
\text { countries, products }\end{array}$ & 2,89 & 38,3 & 33,8 & & \\
\hline Provision of specialized services & 2,89 & 38,5 & 35,6 & & \\
\hline \multirow{2}{*}{ Provision of value-added services* } & \multirow{2}{*}{2,34} & \multirow{2}{*}{25,4} & \multirow{2}{*}{20,5} & Customers & 2,50 \\
\hline & & & & LSPS & 2,18 \\
\hline
\end{tabular}

Source: Own calculations

\section{B. Methods and contents of communication}

Table 2 presents the descriptive statistics and the results of the t-test for the scales measuring the methods and contents of communication. The most widely used methods of communication normally are telephone/fax and electronic methods. Nevertheless, according to the present results, the extent of usage of team meetings and joint teams is quite low. Around $30 \%$ of the companies organize meetings between personnel from both parties and only one of every sixth company has established joint teams. This would indicate that an appropriate environment for knowledge sharing and joint planning has not been created so far concerning logistics outsourcing business relations. This conclusion is supported by the results of the analysis of communication contents. Both groups, quite normally again, ranked delivery terms, prices and customer service levels in the top three areas that occur often or very often in the communication with the other party. However, elements that are important for material flows integration, such as forecasts, promotional plans, inventories and costs, as well as knowledge-related issues and joint planning, are considered much less important to be included in the communication with the other party. There are only three statistically significant differences here and they concern exactly these same issues. Customers seem to perceive that sharing of knowledge and experience concerning quality and material and information flows is less frequent than the perceptions of the LSPs. This result points to the importance of increasing the occurrence of this communication area. At the same time customers face fewer problems in sharing costs and inventory information perhaps due to the fact that logistics costs have an effect on their prices or profits and that in most cases they bear the capital cost of inventory held in LSPs' warehouses.

Table 2. Methods and contents of communication

\begin{tabular}{|c|c|c|c|c|c|}
\hline Communication aspects & Mean & $\begin{array}{l}\text { Responses } \\
4-5(\%) \text { for } \\
\text { customers }\end{array}$ & $\begin{array}{c}\text { Responses } \\
4-5 \text { (\%) for } \\
\text { LSPs }\end{array}$ & Groups & $\begin{array}{c}\text { Group's } \\
\text { mean }\end{array}$ \\
\hline \multicolumn{4}{|l|}{ Methods of communication } & & \\
\hline Telephone/fax & 4,62 & 88,7 & 93,2 & & \\
\hline Electronic communication & 3,82 & 84,2 & 85,1 & & \\
\hline Team meetings & 2,63 & 30,1 & 29 & & \\
\hline Joint teams & 2,06 & 15,8 & 16,9 & & \\
\hline \multicolumn{4}{|l|}{ Contents of communication } & & \\
\hline Delivery terms & 3,92 & 73,5 & 64 & & \\
\hline Prices & 3,47 & 59,8 & 50,4 & & \\
\hline Customer service levels & 3,38 & 46,6 & 55,6 & & \\
\hline Knowledge and experience & 2,90 & 32,3 & 48,8 & Customers & 2,70 \\
\hline
\end{tabular}




\begin{tabular}{|c|c|c|c|c|c|}
\hline $\begin{array}{l}\text { concerning quality and material and } \\
\text { information flows management** }\end{array}$ & & & & LSPs & 3,11 \\
\hline Forecasts & 2,67 & 30 & 34,4 & & \\
\hline $\begin{array}{l}\text { Joint plans for growth and } \\
\text { development }\end{array}$ & 2,61 & 34,1 & 31,7 & & \\
\hline \multirow{2}{*}{ Costs*** } & \multirow{2}{*}{2,60} & \multirow{2}{*}{42,4} & \multirow{2}{*}{24,8} & Customers & 2,96 \\
\hline & & & & LSPS & 2,22 \\
\hline Promotional plans & 2,48 & 26,7 & 30,4 & & \\
\hline \multirow{2}{*}{ Inventories** } & \multirow{2}{*}{2,33} & \multirow{2}{*}{28,5} & \multirow{2}{*}{17,9} & Customers & 2,54 \\
\hline & & & & LSPS & 2,11 \\
\hline $\begin{array}{l}\text { Knowledge and experience in } \\
\text { company management }\end{array}$ & 2,33 & 21,4 & 23,2 & & \\
\hline
\end{tabular}

Source: Own calculations

\section{Relationship management aspects}

The next research area is relationship management and the results concerning its aspects are illustrated in Table 3. Highly ranked are practices such as existence of trust, mutual help in solving problems, provision of feedback and consideration of the financial interests of the other party. All of them receive means close to or above 3,5, which is an evidence of the existence of a solid base for the establishment of collaborative relationships. However, issues concerning consistency of performance measurement in the supply chain have very low scores. In this line, it is expected that common methodology for performance measurement is on the bottom of the list with a mean of 2,27 . The negligence of the consistency and sharing of goals and performance indicators threatens the flawless movement of the material flows in the supply chain and thereby customer service levels could be deteriorated and logistics costs could increase. What is more, providing confidential information to reduce costs is a rare practice too, which supports this conclusion.

As a whole, LSPs exhibited a significantly higher relevance, compared to the manufacturing and trading companies, of seven from all possible ten aspects. The difference is very large in relation to trust, mutual help in solving problems and performance issues such as provision of feedback and consistency of goals and performance indicators. Apparently, customers do not view their relationships with the LSPs as so collaborative as viewed by the LSPs.

Table 3. Relationship management aspects

\begin{tabular}{|c|c|c|c|c|c|}
\hline Relationship management aspects & Mean & $\begin{array}{l}\text { Responses } \\
4-5 \text { (\%)for } \\
\text { customers }\end{array}$ & $\begin{array}{l}\text { Responses } \\
4-5 \text { (\%)for } \\
\text { LSPs }\end{array}$ & Groups & $\begin{array}{l}\text { Group's } \\
\text { mean }\end{array}$ \\
\hline \multirow{2}{*}{ Existence of trust*** } & \multirow{2}{*}{4,35} & \multirow{2}{*}{72,5} & \multirow{2}{*}{93,5} & Customers & 4,09 \\
\hline & & & & LSPS & 4,62 \\
\hline \multirow{2}{*}{ Mutual help in solving problems*** } & \multirow{2}{*}{3,79} & \multirow{2}{*}{42,4} & \multirow{2}{*}{79,2} & Customers & 3,28 \\
\hline & & & & LSPS & 4,29 \\
\hline \multirow{2}{*}{ Provision of feedback*** } & \multirow{2}{*}{3,67} & \multirow{2}{*}{48,5} & \multirow{2}{*}{76,7} & Customers & 3,23 \\
\hline & & & & LSPS & 4,12 \\
\hline $\begin{array}{l}\text { Each party considers the financial } \\
\text { interests of the other one }\end{array}$ & 3,43 & 54,2 & 53,1 & & \\
\hline \multirow{2}{*}{ Consistent goals*** } & \multirow{2}{*}{3,13} & \multirow{2}{*}{31,1} & \multirow{2}{*}{68,5} & Customers & 2,55 \\
\hline & & & & LSPS & 3,73 \\
\hline $\begin{array}{l}\text { Knowledge of the other party's } \\
\text { logistics strategy }\end{array}$ & 3,12 & 41,7 & 40,6 & & \\
\hline \multirow{2}{*}{ Consistent performance indicators $* * *$} & \multirow{2}{*}{2,70} & \multirow{2}{*}{25} & \multirow{2}{*}{41,1} & Customers & 2,33 \\
\hline & & & & LSPS & 3,09 \\
\hline Sharing performance indicators & 2,57 & 28,8 & 30,5 & & \\
\hline Providing confidential information to & 2,51 & 24,2 & 32,3 & Customers & 2,36 \\
\hline
\end{tabular}




\begin{tabular}{|l|l|l|l|l|l|}
\hline reduce costs* & & & & LSPS & 2,65 \\
\hline $\begin{array}{l}\text { Common methodology for } \\
\text { performance measurement }\end{array}$ & 2,27 & 17,4 & 23,3 & & \\
\hline
\end{tabular}

Source: Own calculations

\section{The Relations of Communication and Relationship Management AspeCts to Customer Satisfaction}

The focus in this section is on the communication and relationship management issues that influence customer satisfaction. For that reason, customers are divided into two groups. The first group, with a satisfaction level higher than the overall mean of 3,76 , consists of 91 companies with a median number of 50 employees. The second group consists of 47 companies with a median number of 53 employees. It seems that the size of the company does not affect the satisfaction level. Although $2 / 3$ rd of the customers indicated high levels of satisfaction with the service providers, $1 / 3$ still exhibited high dissatisfaction levels.

Table 4 shows the statistically significant differences in the communication and relationship management aspects between the two groups of companies. Significant association exists between customer satisfaction and three of the four methods of communication, among which are team meetings and joint teams. The contribution of team meetings to customer satisfaction is particularly strong. Similarly, there is the significant contribution to customer satisfaction of sharing knowledge and experience concerning quality, material and information flows management and developing joint plans for growth and development. The that can be drawn is that knowledge sharing and mutual planning in a face-to-face environment is seen by customers to be essential for their success.

There are significant relations to customer satisfaction of four relationship management aspects and these relations appear to be very strong. More concretely, building trust, helping the other party solve problems, understanding the other party's logistics strategy and considering its financial interests contribute significantly to customer satisfaction. These are quite soft issues to manage and there are a lot of challenges associated with them. Nevertheless, they are potentially powerful tools in providing business success for both parties because they provide the background for the implementation of effective supply chain management practices.

Table 4. Relations of communication and relationship management aspects to customer satisfaction

\begin{tabular}{|c|c|c|c|c|}
\hline $\begin{array}{l}\text { Communication and relationship management } \\
\text { aspects }\end{array}$ & \begin{tabular}{|l|} 
Level of \\
customer \\
satisfaction
\end{tabular} & Mean & $\begin{array}{l}\text { Std. } \\
\text { Deviation }\end{array}$ & $\begin{array}{l}\mathrm{p}- \\
\text { value }\end{array}$ \\
\hline \multicolumn{5}{|l|}{ Methods of communication } \\
\hline \multirow{2}{*}{ Telephone/fax } & $>=3,76$ & 4,71 & 0,707 & \multirow{2}{*}{0,029} \\
\hline & $<3,76$ & 4,37 & 0,998 & \\
\hline \multirow{2}{*}{ Team meetings } & $>=3,76$ & 2,91 & 1,387 & \multirow{2}{*}{0,007} \\
\hline & $<3,76$ & 2,21 & 1,143 & \\
\hline \multirow{2}{*}{ Joint teams } & $>=3,76$ & 2,20 & 1,416 & \multirow{2}{*}{0,016} \\
\hline & $<<3,76$ & 1,58 & 1,004 & \\
\hline \multicolumn{5}{|l|}{ Contents of communication } \\
\hline \multirow{2}{*}{$\begin{array}{l}\text { Knowledge and experience concerning quality and } \\
\text { material and information flows management }\end{array}$} & $>=3,76$ & 2,85 & 1,419 & \multirow{2}{*}{0,012} \\
\hline & $<3,76$ & 2,19 & 1,076 & \\
\hline \multirow{2}{*}{ Joint plans for growth and development } & $>=3,76$ & 3,05 & 1,454 & \multirow{2}{*}{0,034} \\
\hline & $<3,76$ & 2,47 & 1,156 & \\
\hline \multicolumn{5}{|l|}{ Relationship management aspects } \\
\hline \multirow{2}{*}{ Existence of trust } & $>=3,76$ & 4,27 & 0,979 & \multirow{2}{*}{0,004} \\
\hline & $<3,76$ & 3,71 & 1,037 & \\
\hline \multirow{2}{*}{ Mutual help in solving problems } & $>=3,76$ & 3,51 & 1,262 & \multirow{2}{*}{0,005} \\
\hline & $<3,76$ & 2,82 & 1,182 & \\
\hline Knowledge of the other party's logistics strategy & $>=3,76$ & 3,36 & 1,646 & 0,006 \\
\hline
\end{tabular}




\begin{tabular}{|l|l|l|l|l|}
\hline & $<3,76$ & 2,53 & 1,246 & \\
\hline \multirow{2}{*}{$\begin{array}{l}\text { Each party considers the financial interests of the } \\
\text { other one }\end{array}$} & $>=3,76$ & 3,70 & 1,391 & \multirow{2}{*}{0,003} \\
\cline { 2 - 4 } & $<3,76$ & 2,92 & 1,194 & \\
\hline
\end{tabular}

Source: Own calculations

\section{CONCLUSIONS AND IMPLICATIONS}

The decision to outsource is taken due to various rationales rooted in the desire of companies to add value for their customers and to decrease costs. Understanding these rationales is important for LSPs in order to provide services with high quality. In many cases they perceive differently from their customers their motives to outsource and the building blocks of the relationships established afterwards. This may lead to lower customer satisfaction and finally to lower value added for the end customer. In this line, a comparison of LSPs and LSPs' customers (manufacturing and trading companies) concerning motives, communication and relationship management issues is considered important in drawing valuable conclusions.

The results of this research proved that the reasons why companies decide to outsource logistics are very diverse and the service related ones are prevailing. This result speaks about a greater stress on the quality of services. The overestimation by LSPS, compared to manufacturing and trading companies, of nearly half of the motives concerning service, organizational capabilities and relationships reveals the confidence of the LSPs that their services are much needed and demanded by the companies and their belief that logistics outsourcing will continue to be a modern trend. Actually, recent survey results evidence that $26 \%$ of shippers report they are returning to insourcing at least some of their logistics activities [19]. The implication is that in order to decrease the number of insourcing companies and attract more customers, the service-provision sector should not use low costs only as a selling criterion. LSPs should rather stress on the improvement of service offerings and the quality-price ratio. The fact that customers give much emphasis on the provision of value-added services and the availability of contemporary logistics assets shows the direction, in which LSPs should develop.

The research also found that both the LSPs and their customers consider that the extent of sharing of knowledge and information essential for material flow integration is very low and the usage of team meetings and joint teams is quite rare. This supposes that the chances to achieve high levels of integration of these important supply chain members are very small. Another important result indicates that customers of 3PL's do not consider their relationships with the LSPs as much collaborative because they, compared to LSPs, give lower assessment of relationship characteristics like trust, mutual help in solving problems, provision of feedback and consistency of goals and performance indicators. This mismatch, especially concerning performance measurement, shows that customers see a lot of opportunities to increase the benefits from outsourcing beyond mere cost reduction.

The research evidenced, as well, that significant positive relations exist between customer satisfaction and communication through team meetings and joint teams, knowledge sharing concerning material flows management and relationship management issues such as trust, joint problem solving, understanding the logistics strategy of the other party and respecting the other party's financial interests. This effect highlights the importance of knowledge sharing and trust building and reveals great potential for effective trust-based alliances between LSPS and their customers to help them extract more competitive benefits from their relationships.

A limitation of the research is that it is conducted in Bulgaria and the findings might not be valid for other countries. Therefore, in order to generalize the results across a larger region or to make comparative analyses between countries, other studies with similar methodologies should be carried out across samples from different countries.

\section{REFERENCES}

1. K. Gotzamani, P. Longinidis, and F. Vouzas, "The logistics services outsourcing dilemma: quality management and financial performance perspectives", Supply Chain Management: An International Journal, vol. 15, no. 6 pp. 438-453, September 2010.

2. S. J. Grawe, P. J. Daugherty, and P. M. Ralston, "Enhancing dyadic performance through boundary spanners and innovation: An assessment of service provider-customer relationships", Journal of Business Logistics, vol. 36, no. 1, pp. 88-101, March. 2015.

3. P. R. Murphy and R. Poist, "Third-party logistics usage: an assessment of propositions based on previous research", Transportation Journal, vol. 37, no. 4, pp. 26-35, Summer 1998. 
4. D. Power, M. Sharafali, and V. Bhakoo, "Adding value through outsourcing", Management Research News, vol. 30, no. 6, pp. 228-235, February 2007.

5. Y. Song, T. E. Maher, J. D. Nicholson, and N. P. Gurney, "Strategic alliances in logistics outsourcing", Asia Pacific Journal of Marketing and Logistics, vol. 12, no. 4, pp. 3-21, December 2000.

6. H. S. Jaafar and M. Rafiq, "Logistics outsourcing practices in the UK: a survey", International Journal of Logistics Research and Applications: A Leading Journal of Supply Chain Management, vol. 8, no. 4, pp. 299-312, January 2005.

7. S. Boyson, T. Corsi, M. Dresner, and E. Rabinovich, "Managing effective third party relationships: What does it take?", Journal of Business Logistics, vol. 20, no. 1, pp. 73-97, 1999.

8. R. Lieb and B. A. Bentz, "The use of third-party logistics services by large American manufacturers: The 2004 survey," Transportation Journal, vol. 44, no. 2, pp. 5-15, Spring 2005.

9. T. Solakivi, J. Töyli, and L. Ojala, "Logistics outsourcing, its motives and the level of logistics costs in manufacturing and trading companies operating in Finland", Production Planning \& Control: The Management of Operations, vol. 24, no. 4-5, pp. 388-398, January 2013.

10. S. E. Fawcett, A. M. Fawcett, B. J. Watson, and G. M. Magnan, "Peeking Inside the black box: Toward an understanding of supply chain collaboration dynamics", Journal of Supply Chain Management, vol. 48, no. 1, pp. 44-72, January 2012.

11. S. J. Grawe, P. J. Daugherty, and A. S. Roath, "Knowledge synthesis and innovative logistics processes: Enhancing operational flexibility and performance", Journal of Business Logistics, vol. 32, no. 1, pp. 69-80, March 2011.

12. J. H. Dyer and H. Singh, "The relational view: Cooperative strategy and sources of interorganizational competitive advantage", Academy of Management Review, vol. 23, no. 4, pp. 660-79, October 1998.

13. J. Jayaram and K. Tan, "Supply chain integration with third-party logistics providers", Int. J. Production Economics, vol. 125, no. 2, pp. 262-271, June 2010.

14. K. J. Petersen, R. B. Handfield, B. Lawson, and P. D. Cousins, "Buyer dependency and relational capital formation: The mediating effects of socialization processes and supplier integration", Journal of Supply Chain Management, vol. 44, no. 4, pp. 53-65, September 2008.

15. K. M. Eisenhardt and C. B. Schoonhoven, "Resource-based view of strategic alliance formation: Strategic and social effects in entrepreneurial firms", Organization Science, vol. 7, no. 2, pp. 136-50, March-April 1996.

16. P. D. Cousins, B. Lawson, K. J. Petersen, and R. B. Handfield, "Breakthrough scanning, supplier knowledge exchange, and new product development performance", Journal of Product Innovation Management, vol. 28, no. 5, pp. 930-42, November 2011

17. H. I. Hsiao, R. G. M. Kemp, J. G. A. J. van der Vorst, and S. W. F. (Onno) Omta, "A classification of logistic outsourcing levels and their impact on service performance: Evidence from the food processing industry", Int. J. Production Economics, vol. 124, no. 1, pp. 75-86, March 2010.

18. J. E. Mello, T. P. Stank, and T. L. Esper, "A model of logistics outsourcing strategy", Transportation Journal, vol. 47, no. 4, pp. 5-25, Fall 2008.

19. Langley, J. and CapGemini, Third-Party Logistics Study. The State of Logistics Outsourcing. Results and Findings of the 19th Annual Study, 2015.

\section{AUTHOR}

M. Rakovska is with the University of National and World Economy, Logistics Department, Economics of Infrastructure Faculty, 1700 Sofia, Students Town, Sofia, Bulgaria (email: mirar@unwe.bg) 